\title{
Neuronal Basic Helix-Loop-Helix Proteins Neurod2/6 Regulate Cortical Commissure Formation before Midline Interactions
}

\author{
Ingo Bormuth, ${ }^{1,2 *}$ Kuo Yan,,${ }^{2 *}$ Tomoko Yonemasu, ${ }^{1}$ Maike Gummert, ${ }^{1}$ Mingyue Zhang, ${ }^{3}$ Sven Wichert, ${ }^{1}$ Olga Grishina, ${ }^{2 *}$ \\ Alexander Pieper, ${ }^{1}$ Weiqi Zhang, ${ }^{3}$ Sandra Goebbels, ${ }^{1}$ Victor Tarabykin, ${ }^{2}$ Klaus-Armin Nave, ${ }^{1}$ and Markus H. Schwab ${ }^{1}$ \\ ${ }^{1}$ Max Planck Institute of Experimental Medicine, Department of Neurogenetics, D-37075 Göttingen, Germany, ${ }^{2}$ Charité-Universitätsmedizin Berlin, \\ Institute of Cell Biology and Neurobiology, NeuroCure Cluster of Excellence, D-10115 Berlin, Germany, and ${ }^{3}$ University of Münster, Department of \\ Psychiatry, Laboratory of Molecular Psychiatry, D-48149 Münster, Germany
}

Establishment of long-range fiber tracts by neocortical projection neurons is fundamental for higher brain functions. The molecular control of axon tract formation, however, is still poorly understood. Here, we have identified basic helix-loop-helix (bHLH) transcription factors Neurod 2 and Neurod6 as key regulators of fasciculation and targeted axogenesis in the mouse neocortex. In Neurod2/6 double-mutant mice, callosal axons lack expression of the cell adhesion molecule Contactin2, defasciculate in the subventricular zone, and fail to grow toward the midline without forming Probst bundles. Instead, mutant axons overexpress Robol and follow random trajectories into the ipsilateral cortex. In contrast to long-range axogenesis, generation and maintenance of pyramidal neurons and initial axon outgrowth are grossly normal, suggesting that these processes are under distinct transcriptional control. Our findings define a new stage in corpus callosum development and demonstrate that neocortical projection neurons require transcriptional specification by neuronal bHLH proteins to execute an intrinsic program of remote connectivity.

\section{Introduction}

Three commissural fiber tracts connect the cerebral hemispheres in placental mammals: the hippocampal commissure (HC), the anterior commissure (AC), and the corpus callosum (CC), the evolutionary youngest telencephalic fiber tract, which interconnects the neocortex (Mihrshahi, 2006). The complexity of commissure formation is illustrated by the frequency of complete or partial CC agenesis in humans (1:4000 individuals; associated

\footnotetext{
Received Feb. 23, 2012; revised 0ct. 29, 2012; accepted Nov. 5, 2012

Author contributions: I.B., S.G., V.T., K.-A.N., and M.H.S. designed research; I.B., K.Y., M.G., M.Z., S.W., O.G., and A.P. performed research; T.Y. and S.G. contributed unpublished reagents/analytic tools; I.B., W.Z., V.T., and M.H.S. analyzed data; I.B., W.Z., V.T., K.-A.N., and M.H.S. wrote the paper.

This work was supported by the German Research Foundation Excellence Cluster NeuroCure (Exc 257) (I.B. and V.T.), the Heisenberg Program (V.T.), the German Research Foundation Research Center of Molecular Physiology of the Brain (M.H.S. and K.A.N.), and German Research Foundation Grant SFB-TRR 58 TP A08 (W.Z.). We thank A. Fahrenholz, G. Fricke-Bode, U. Bode, M. Flörl, and R. Wunderlich for excellent technical assistance. We also thank the mouse facility Max Planck Institute Göttingen and especially D. Rhode and C. Casper for animal care and excellent cooperation. We are grateful to H. Kume and K. Maruyama for Neurod2 genomic DNA, L. Schrama for the Gap43 in situ hybridization probe, J. E. Visvader for $L$ mo4 antibody, and F. Murakami for Robo 1 antibody. Monoclonal antibody 4D7/TAG1/Cntn2 (developed by M. Yamamoto) was obtained from the Developmental Studies Hybridoma Bank (http://dshb.biology.uiowa.edu) developed under the auspices of the National Institute of Child Health and Human Development and maintained by the University of lowa, Department of Biology (lowa City, IA).

*I.B. and K.Y. contributed equally to this work.

The authors declare no competing financial interests.

Correspondence should be addressed to any of the following: Dr. Markus Schwab or Klaus-Armin Nave, Max Planck Institute of Experimental Medicine, Department of Neurogenetics, Hermann-Rein-Strasse 3, 37075 Göttingen,Germany, E-mail:schwab@em.mpg.de or nave@em.mpg.de; or Victor Tarabykin,Charité-Universitätsmedizin Berlin, Institute of Cell and Neurobiology, CCO, Charitéplatz 1, 10117 Berlin, Germany, E-mail: victor. tarabykin@charite.de.

DOI:10.1523/JNEUROSCI.0899-12.2013

Copyright $\odot 2013$ the authors $\quad 0270-6474 / 13 / 330641-11 \$ 15.00 / 0$
}

with $>28$ syndromes), which impairs emotional, social, and mental functions (Paul et al., 2007).

Neocortical projection neurons are produced between embryonic day 11 (E11) and E17 of mouse development from proliferating precursor cells in the ventricular (VZ) and subventricular (SVZ) zones of the dorsal telencephalon (Angevine and Sidman, 1961; Molyneaux et al., 2007). After radial migration, postmitotic neurons settle in the cortical plate (CP) and initiate terminal differentiation. The subsequent development of projection pathways includes initial axon outgrowth, fasciculation, pathfinding, and target area innervation (Richards et al., 2004; Barnes and Polleux, 2009). Multiple effector molecules (e.g., axonal and dendritic guidance receptors) have been identified that mediate these processes (Innocenti and Price, 2005; Arimura and Kaibuchi, 2007; Lindwall et al., 2007; Parrish et al., 2007; O’Donnell et al., 2009). The majority of transcription factors that have been studied in cortical development are enriched in distinct cortical layers or are expressed in gradients along rostrocaudal or lateromedial axes (Molyneaux et al., 2007; Sansom and Livesey, 2009). These factors typically confer layer- or area-specific identity, and axon bundle formation is not completely abolished in corresponding mouse mutants (Donahoo and Richards, 2009). Thus, it remains unresolved, whether projection neurons require previous genetic specification to turn into long-range projection neurons.

Neuronal basic helix-loop-helix (bHLH) proteins Neurod2 (NDRF) and Neurod6 (NEX, Math2) are atonal-related transcription factors and candidates to specify aspects of the projection neuron phenotype. Neocortical expression occurs first in neuronal precursors committed to the pyramidal cell lineage 


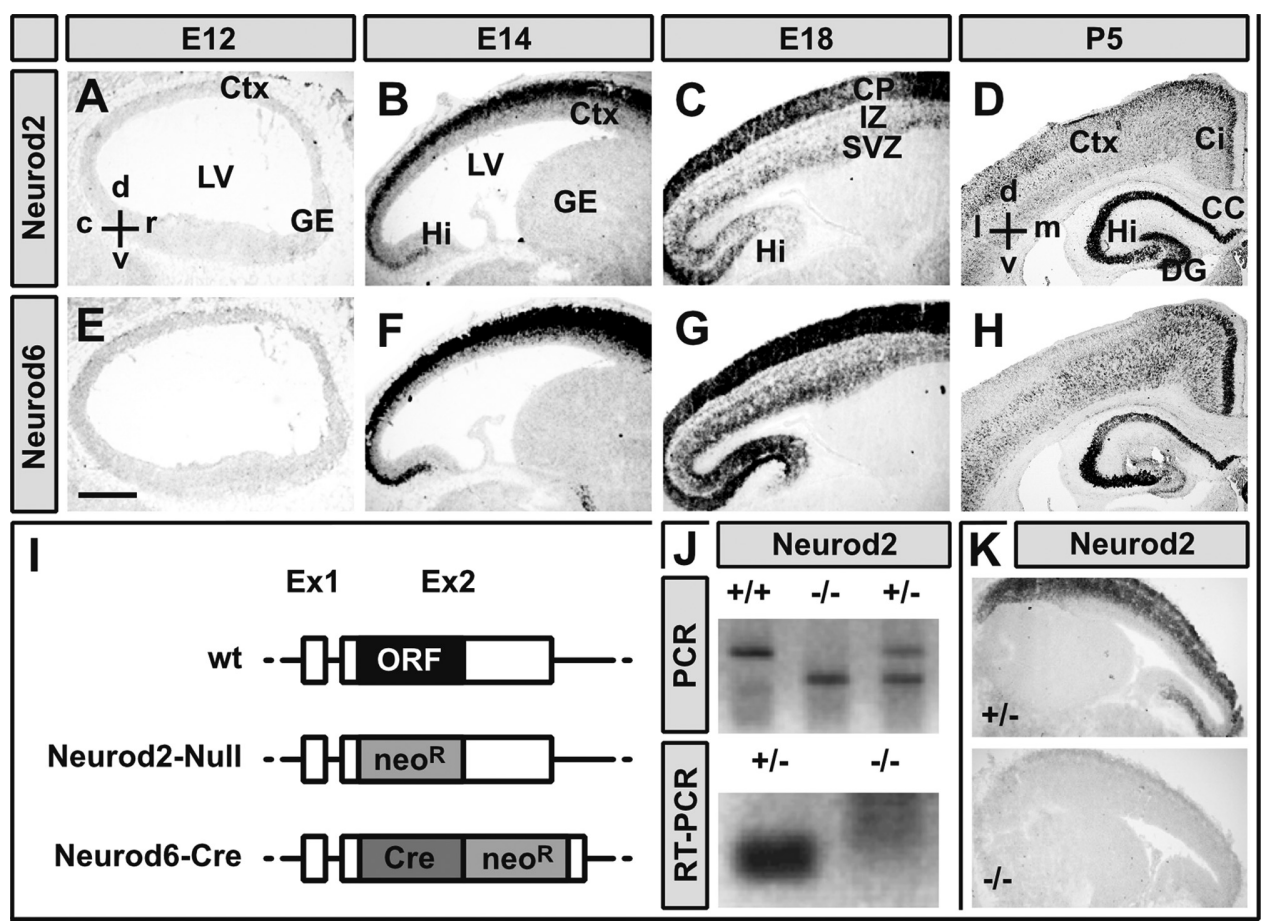

Figure 1. Highly overlapping expression of Neurod2/6 during cortical development. $\boldsymbol{A}-\boldsymbol{H}$, Chromogenic in situ hybridization of immediately adjacent sagittal $(\boldsymbol{A}-\boldsymbol{C}, \boldsymbol{E}-\mathbf{G})$ and frontal $(\boldsymbol{D}, \boldsymbol{H})$ cryosections $(14 \mu \mathrm{m})$ from mouse brains at indicated embryonic and postnatal stages with cRNA probes directed against Neurod2 $(\boldsymbol{A}-\boldsymbol{D})$ and Neurod6 (E-H) mRNA. $\boldsymbol{I}-\boldsymbol{K}$, Inactivation of the Neurod2 gene. Schematic drawings of a prototypic wild-type neuronal bHLH gene locus (wt) and constitutive mutant alleles of the Neurod2 (Neurod2-Null) and Neurod6 (Neurod6-Cre) gene (I). Inactivation of the Neurod2 gene was confirmed by PCR on genomic DNA (J), RT-PCR on total RNA from laser-dissected neocortex at P1 $(\boldsymbol{J})$, and in situ hybridization at P1 (K).Scale bar, $500 \mu \mathrm{m}$. C, Caudal; $d$, dorsal; I, lateral; $\mathrm{m}$, medial; $\mathrm{r}$, rostral; v, ventral; Ci, cingulate cortex; Ctx, cerebral cortex; DG, dentate gyrus; GE, ganglionic eminence; Hi, hippocampus; IZ, intermediate zone; LV, lateral ventricle; neo ${ }^{R}$, neomycin resistance cassette.

(Wu et al., 2005; Goebbels et al., 2006), is prominent during embryonic development (Bartholomä and Nave, 1994; Schwab et al., 1998), and is maintained in subsets of pyramidal neurons of the mature neocortex, hippocampus, and amygdala (Schwab et al., 1998; Lin et al., 2004; Agarwal et al., 2012). The analysis of mouse mutants revealed critical functions of neuronal bHLH proteins in granule neurons of dentate gyrus and cerebellum (Liu et al., 2000; Schwab et al., 2000; Olson et al., 2001), as well as for the patterning of thalamocortical projections and synaptic maturation (Ince-Dunn et al., 2006; Yang et al., 2009). Recently, it was shown that Neurod6 is expressed in subsets of amacrine cells in the retina and regulates amacrine cell fate (Cherry et al., 2011; Kay et al., 2011). However, the function of Neurod2 and Neurod6 in cortical projection neurons remains poorly understood, mainly because of the lack of informative phenotypes in single null mutants.

Here, we report that neocortical projection neurons require transcriptional specification by neuronal bHLH proteins $\mathrm{Neu}$ rod2/6 for axonal fasciculation and proper formation of callosal fiber tracts. In contrast, initial axon outgrowth and glutamatergic synaptogenesis are under distinct transcriptional control.

\section{Materials and Methods}

Mouse mutants. All animal experiments were performed in compliance with approved animal policies of the Max Planck Institute of Experimental Medicine (Göttingen, Germany). Neurod6-Cre mice were genotyped as described previously (Goebbels et al., 2006). Neurod2-null mutant mice were generated by replacing the coding region on exon 2 with a neomycin resistance cassette in reverse orientation using homologous recombination in embryonic stem cells (Fig. $1 I-K$ ). Routine genotyping was performed by PCR using primers Neurod2-s (5'-TGG GCT CTC TCG GAG ATC T-3'), revNeo-s ( $5^{\prime}$-ATT GTC TGT TGT GCC CAG TC-3'), and Neurod2-as ( $5^{\prime}$-CTG TTG GGA GGT GGG GAG AG-3').
Neurod 2 and Neurod6 single mutants were initially bred into a C57BL/6 genetic background. Neurod 2 mutants died at 3 weeks of age (consistent with Olson et al., 2001), and Neurod2/6 double mutants died immediately after birth. Breeding C57BL/6-based mutants for four generations to a $129 /$ SvJ genetic background (motivated by Huang et al., 2002) resulted in a normal lifespan of most Neurod 2 mutants and extended the survival of Neurod $2 / 6$ double mutants by several hours. AC and CC agenesis in Neurod $2 / 6$ double mutant was observed in pure C57BL/ 6 and hybrid C57BL/6×129/SvJ genetic background. We never observed Probst bundles PBs or CC agenesis in control mice with a mixed C57BL/ $6 \times 129 / \mathrm{SvJ}$ genetic background. Experiments were done using mice of either sex.

Histology. Heads of embryos and newborn mice were immersion fixed in neutral buffered Formalin (NBF; 4\% Formalin in PBS) for $1 \mathrm{~h}$. Adult mice were intracardially perfused with NBF. Brains were postfixed in NBF for $1 \mathrm{~h}$ to overnight at $4^{\circ} \mathrm{C}$. For cryosections, brains were immersed in 20 and 30\% sucrose overnight, embedded in OCT, and cut to $16 \mu \mathrm{m}$ sections on a CM3000 cryostat (Leica). For paraffin sections, brains were dehydrated using an ascending ethanol series, isopropanol, and xylene, embedded in paraffin, and cut to $5-10 \mu \mathrm{m}$ sections on a sliding microtome (Leica). For labeling of single cortical neurons, brains were cut to $100 \mu \mathrm{m}$ sections using a vibratome (Leica), and single cells were filled with Lucifer yellow using a patch pipette and iontophoresis.

In situ hybridization. Brains were fixed in $4 \%$ paraformaldehyde (PFA) in diethylpyrocarbonate (DEPC) kept in phosphate buffer $(0.1 \mathrm{M}$ $\mathrm{Na}_{2} \mathrm{HPO}_{4}, \mathrm{pH} 10$ ) containing 15 and $30 \%$ sucrose overnight, embedded in OCT, and snap frozen on dry ice. Cryostat sections $(16 \mu \mathrm{m})$ were collected on adhesive glass slides, dried at room temperature using a vacuum exicator for $1-2 \mathrm{~h}$, postfixed in $4 \%$ PFA in phosphate bufferDEPC for 15 min, washed in PBS-DEPC, $\mathrm{pH} 7.4$, and incubated with 20 $\mu \mathrm{g} / \mathrm{ml}$ Proteinase $\mathrm{K}$ in $20 \mathrm{~mm}$ Tris, $\mathrm{pH} 7.5$, and 1 mM EDTA, pH 8, for 2.5 min. Proteinase K was inactivated in $0.2 \%$ glycine in PBS-DEPC, and sections were washed in PBS-DEPC, postfixed in 4\% PFA and $0.2 \%$ glutaraldehyde in PBS-DEPC for 20 min, washed in PBS-DEPC, prehy- 
bridized in hybridization buffer [ $50 \%$ formamide, $5 \times$ SSC, $\mathrm{pH} 4.5,1 \%$ blocking reagent (Roche), 5 mm EDTA, 0.1\% Tween 20, 0.1\% CHAPS, $0.1 \mathrm{mg} / \mathrm{ml}$ heparin, and $100 \mu \mathrm{g} / \mathrm{ml}$ yeast RNA in DEPC-water] at $70^{\circ} \mathrm{C}$ for $2 \mathrm{~h}$, and hybridized overnight in hybridization buffer containing digoxigenin (DIG)-labeled and denatured cRNA probe at $70^{\circ} \mathrm{C}$. Slides were rinsed in SSC, $\mathrm{pH} 4.5$, treated with $20 \mu \mathrm{g} / \mathrm{ml} \mathrm{RNase}$ in $0.5 \mathrm{M} \mathrm{NaCl} / 10 \mathrm{~mm}$ Tris for $30 \mathrm{~min}$ at $37^{\circ} \mathrm{C}$, rinsed in $2 \times \mathrm{SSC}, \mathrm{pH} 4.5$, washed three times in $50 \%$ formamide in $2 \times \mathrm{SSC}, \mathrm{pH} 4.5$, for $30 \mathrm{~min}$ at $65^{\circ} \mathrm{C}$, rinsed in $50 \mathrm{~mm}$ Tris, $\mathrm{pH}$ $7.5,150 \mathrm{~mm} \mathrm{NaCl}, 10 \mathrm{~mm} \mathrm{KCl}, 1 \%$ Triton-X (KTBT), blocked in 20\% sheep serum in KTBT $(\mathrm{KTBT}+\mathrm{S})$ for $2 \mathrm{~h}$, incubated with anti-DIG alkaline phosphatase antibody (Roche) at 1:1000 in KTBT + S overnight at $4^{\circ} \mathrm{C}$, washed in KTBT, washed four times in KTBT for $30 \mathrm{~min}$, washed in $100 \mathrm{~mm}$ Tris, $\mathrm{pH}$ 9.5, $100 \mathrm{~mm} \mathrm{NaCl}, 50 \mathrm{~mm} \mathrm{MgCl}_{2}, 0.05 \%$ Tween 20 (NTMT), and developed in NBT/BCIP in NTMT for $1-48 \mathrm{~h}$ at $37^{\circ} \mathrm{C}$.

Immunohistochemistry. Paraffin sections were deparaffinized using xylene and isopropanol and rehydrated in a descending ethanol series. Antigen unmasking was performed by boiling for 10-40 min in citric buffer, pH 6, or Tris EDTA, pH 9. Sections were blocked in 20\% goat serum in PBS/BSA for $1 \mathrm{~h}$ and incubated with primary antibodies in 5\% goat serum in PBS/BSA for $2 \mathrm{~h}$ at $37^{\circ} \mathrm{C}$ or overnight at $4^{\circ} \mathrm{C}$. Detection was done using fluorescent-conjugated secondary antibodies, biotinylated secondary antibodies, followed by diaminobenzidine (DAB) or alkaline phosphatase-coupled secondary antibodies, followed by NTB/BCIP or fast red TR/naphthol.

Primary antibodies were directed against Brn2 (1:200, polyclonal goat; Santa Cruz Biotechnology), CNPase (1:150, mouse IgG; Sigma), Cntn2 (4D7/TAG1, 1:100, mouse IgM; Developmental Studies Hybridoma Bank), Ctip2 (1:500, rat IgG; Abcam), FNP7 (1:100, mouse IgG; Zymed), Gfap (1:200, polyclonal rabbit; Novocastra), GFP (1:500, polyclonal goat; Rockland), HuC/D (1:250, mouse IgG; Invitrogen), L1cam (1:500, polyclonal rat; Millipore Bioscience Research Reagents), Lmo4 (1:500, rat; J. E. Visvader, University of Sydney, Sydney, Australia), Map2 (1:200, mouse IgG; Millipore Bioscience Research Reagents), Nestin (1:100, mouse IgG; Millipore Bioscience Research Reagents), NeuN (1:200, mouse IgG; Millipore Bioscience Research Reagents), NR1 (1:100, polyclonal rabbit; Abcam), Robo1 (1:2000, polyclonal rabbit; F. Murakami), Satb2 (1:1000; V. Tarabykin), Sox5 (1:200, polyclonal goat; R \& D Systems), Tbr2 (1: 200, polyclonal rabbit; Abcam), or Vglut 1 (1:400, polyclonal rabbit; Synaptic Systems). F-actin was stained using Alexa Fluor 555 phalloidin (Invitrogen).

In utero electroporation. The procedure has been described previously (Saito, 2006). Briefly, pregnant dams were anesthetized (intraperitoneal injection of $10 \mu \mathrm{g}$ of xylazine and $100 \mu \mathrm{g}$ of ketamine per gram body weight and an additional subcutaneous injection of buprenorphin for analgesia), the uterine horns were exposed, and plasmid DNA was injected into the embryonic lateral ventricle using a glass pipette connected to an automated microinjector pump. Electroporation (six times at $50 \mathrm{~ms}, 33 \mathrm{~V}$ direct current with $100 \mathrm{~ms}$ intervals) was performed using an ECM 830 electroporator (BTX). The wound was surgically sutured, and the mouse was monitored until full recovery from anesthesia. The procedure was approved by the animal welfare officer of the Max Planck Institute of Experimental Medicine and covered by Gen 33.42502-04-035/07.

Laser-capture microdissection. Mice were killed after birth by cervical dislocation. Heads were placed on dry ice and stored at $-80^{\circ} \mathrm{C}$. Serial coronal cryosections $(20 \mu \mathrm{m})$ were prepared using a Leica CM3000 Cryostat, mounted on polyethylene naphthalate-membrane frame slides (Arcturus), stained with thionin, and dried in an ascending ethanol/xylene series. For laser-capture microdissection (LCM), a Veritas Microdissection System (Arcturus) was used. Cerebral cortex (including SVZ but excluding marginal zone and VZ) was dissected by ultraviolet laser (laser power set to 3.2-4.2) and attached to CapSure LCM caps using an infrared laser (power set to $80 \%$ ). Caps were collected in $0.5 \mathrm{ml}$ Eppendorf tubes containing $100 \mu \mathrm{l}$ of RNeasy Lysis Buffer (Qiagen) and stored at $-80^{\circ} \mathrm{C}$.

$R N A$ isolation, $c D N A$ synthesis, and $q R T-P C R$. Total RNA was isolated from LCM tissue using the Transcriptor High Fidelity Kit (Roche) according to the instructions of the manufacturer. cDNA was synthesized using a mixture of random nonamer primers and anchored poly-dT primers and SuperScript III RNase H reverse transcriptase (Invitrogen) according to the instructions of the manufacturer. qRT-PCR was per-
Table 1. Primer sequences used for qRT-PCR

\begin{tabular}{|c|c|}
\hline Primer & Sequence \\
\hline \multicolumn{2}{|l|}{ Cntn2 } \\
\hline Forward & GGA GCC TGT GCT ACA AGA CA \\
\hline Reverse & CGG CTT TCC AGT AGC GAAT \\
\hline \multicolumn{2}{|l|}{ Cntn1 } \\
\hline Forward & СCT CAT TCC GAT TCC TGA AC \\
\hline Reverse & TCC TTG AAC TGC ACC ACA AT \\
\hline \multicolumn{2}{|l|}{ Robol } \\
\hline Forward & AGG GAA GCC TAC GCA GAT G \\
\hline Reverse & TGG ACA GTG GGC GAT TTT AT \\
\hline \multicolumn{2}{|l|}{ Gap43 } \\
\hline Forward & GGA AGA GAG GAG GAA AGG AGA \\
\hline Reverse & TGG TCC TCA TCA TTC TTT TCA A \\
\hline \multicolumn{2}{|l|}{ L1cam } \\
\hline Forward & TGC TAG CCA ATG CCT ACA TTT \\
\hline Reverse & TGC CAT GTA TGT CTG ATT GTC TTT \\
\hline
\end{tabular}

formed using SYBR green master mix (Applied Biosystems) and a 7500 Fast Real-Time PCR System (Applied Biosystems). Primers (Table 1) were designed using the Roche Universal ProbeLibrary website (http://qpcr.probefinder.com). Relative mRNA concentrations were normalized to $\beta$-actin. Data were analyzed using qBase software version 1.3.5 (Center for Medical Genetics, Ghent University, Ghent, Belgium).

Cell culture. Brains were dissected at E16 or postnatal day 1 (P1) in ice-cold HBSS containing $0.15 \% \mathrm{MgSO}_{4}$ (HBSS+). The neocortex was isolated under a binocular and was incubated in papain $(10 \mathrm{U} / \mathrm{ml}) /$ DNase $(0.25 \mathrm{mg} / \mathrm{ml})$ in HBSS + at $37^{\circ} \mathrm{C}$ for $30 \mathrm{~min}$. The tissue was triturated using a Pasteur pipette, ice cold HBSS + was added, and cells were counted, pelleted, and resuspended in Neurobasal medium (supplemented with penicillin/streptomycin, glutamine, and B-27). A total of 60,000 cells were plated per $7 \mathrm{~mm}$ poly-L-lysine-coated glass coverslip.

Electrophysiology. Recordings were performed on dissociated cortical cell cultures after 21-28 $\mathrm{d}$ in vitro (DIV) in the presence of $1 \mu \mathrm{M}$ bicuculine. The bath solution consisted of the following (in mM): $120 \mathrm{NaCl}, 3$ $\mathrm{KCl}, 2 \mathrm{CaCl}_{2}, 2 \mathrm{MgCl}_{2}, 10 \mathrm{HEPES}$, and 10 glucose, $\mathrm{pH} 7.35$ (aerated with $95 \% \mathrm{O}_{2}$ and $5 \% \mathrm{CO}_{2}$ at $32^{\circ} \mathrm{C}$ ). The pipette solution contained the following (in mM): $140 \mathrm{~K}$-gluconate, $1 \mathrm{CaCl}_{2}, 10 \mathrm{EGTA}, 2 \mathrm{MgCl}_{2}, 4$ $\mathrm{Na}_{3} \mathrm{ATP}, 0.5 \mathrm{Na}_{3} \mathrm{GTP}$, and 10 HEPES, $\mathrm{pH}$ 7.3. Data acquisition and analysis were done using pClamp 9.0 (Molecular Devices) and MiniAnalysis (SynaptoSoft) software.

Image processing. Digital images were obtained using Axiophot (Carl Zeiss) and DM RXA (Leica) microscopes equipped with digital classic DCC cameras (Kappa) or LSM-410 (Carl Zeiss) and SP5 (Leica) confocal microscopes. Images were processed using Gimp-2.6 (http://gimp.org). Figures were assembled using Scribus-1.3.5 (http://www.scribus.net).

Statistical analyses. Cortical neurons were counted by a blinded technician using NIH ImageJ-1.46 (http://rsb.info.nih.gov/ij) with CellCounter plugin (http://rsbweb.nih.gov/ij/plugins/cell-counter.html). Statistical analysis was performed using R-2.8 (http://www.r-project. org). Values are expressed as mean \pm SEM. $p$ values were calculated by unpaired, two-tailed Student's $t$ test, with or without Welch's correction, depending on the distribution of the data (tested with a KolmogorovSmirnov test), and displayed as ${ }^{\star} p<0.05,{ }^{\star *} p<0.01$, and ${ }^{\star * *} p<0.001$.

\section{Results}

Neurod2/6 are coexpressed in neocortical projection neurons During embryonic development, Neurod 2 and Neurod6 are selectively expressed in postmitotic pyramidal neurons of the dorsal telencephalon (Kume et al., 1996; Yasunami et al., 1996; Schwab et al., 1998). To evaluate the degree of expression overlap, we performed chromogenic in situ hybridization on immediate adjacent cryosections from wild-type mouse brains at several developmental stages (Fig. 1). At E12, both transcripts were barely detectable (Fig. 1A,E). Neurod2/6 were robustly coexpressed in the SVZ and CP at E14 (Fig. $1 B, F$ ) and in SVZ, intermediate 


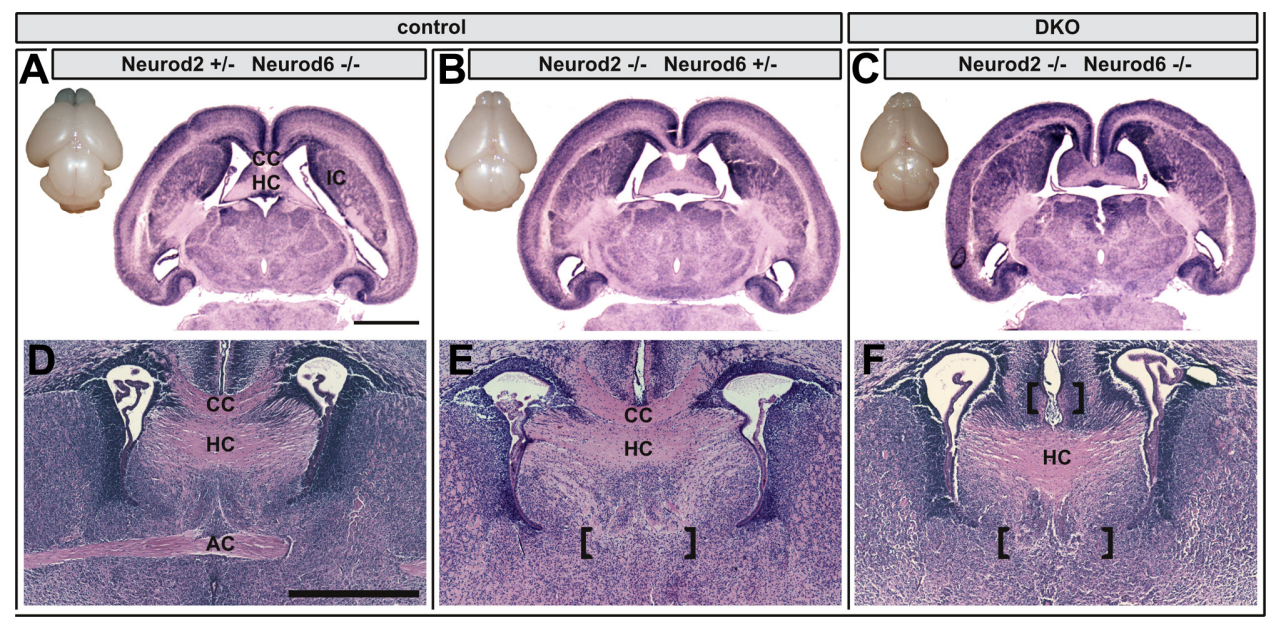

Figure 2. Absence of cortical fiber tracts in Neurod2/6 double mutants. Dorsal views of freshly dissected brains at P1 show the presence of major brain areas in Neurod2 ${ }^{-1-}$;Neurod6 ${ }^{-/-}$double

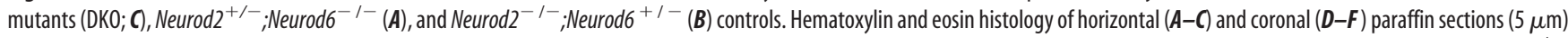
from $\mathrm{P} 1$ brains reveal complete absence of $\mathrm{AC}$ and $\mathrm{CC}$ in double mutants (marked by brackets), whereas the $\mathrm{HC}$ is normally developed $(\boldsymbol{C}, \boldsymbol{F})$. The $\mathrm{AC}$ is already absent in brains from Neurod2 ${ }^{-1-}$; Neurod6 $6^{+/-}$mutants (E) but present in Neurod2 ${ }^{+/-} ;$Neurod6 $^{-1-}(\boldsymbol{D})$ mutants. Scale bars, $1 \mathrm{~mm}$. IC, Internal capsule.

zone, and CP at E18 (Fig. 1C,G). At P5, Neurod2/6 continued to be broadly coexpressed in neocortex and hippocampus (Fig. $1 D, H)$. Neurod 2 transcripts predominated in upper cortical layers, whereas Neurod6 was preferentially expressed in cingulate cortex and deeper cortical layers (Fig. $1 D, H$ ). We conclude that, during embryonic development, Neurod2 and Neurod6 are coexpressed in virtually all postmitotic projection neurons.

\section{Neocortical projections are disrupted in the absence of Neurod $2 / 6$}

Highly overlapping spatial and temporal expression profiles and the lack of obvious defects in pyramidal neurons of Neurod 2 or Neurod6 single-mutant mice (Schwab et al., 1998; Olson et al., 2001) suggested functional redundancy. To test this hypothesis, we produced Neurod2/6 double mutants by breeding Neurod6Cre mice (Goebbels et al., 2006; Fig. 1I) to a novel null mutant of the Neurod2 gene, in which we replaced the Neurod 2 coding region by a neomycin resistance cassette (Fig. 1I). Inactivation of the Neurod 2 gene was verified by PCR on genomic DNA (Fig. $1 J)$. Absence of Neurod2 transcripts was confirmed by RT-PCR on total RNA isolated from P1 cortex (Fig. $1 J$ ) and in situ hybridization on E14 brain sections (Fig. $1 K$ ).

Double-mutant mice were born at the expected Mendelian frequency. Body size, weight, and posture were indistinguishable from littermate controls at birth. However, $>90 \%$ of double mutants died within a few hours after birth. Ataxic breathing and Neurod6 expression in the reticular formation (Goebbels et al., 2006) suggest respiratory failure as the cause of death. Macroscopically, brains from newborn Neurod2/6 double mutants were indistinguishable from wild-type (data not shown) or compound mutants with genotypes Neurod2 $2^{-/-} ;$Neurod $^{+/-}$or Neurod2 ${ }^{+/-}$; Neurod6 ${ }^{-1-}$ (Fig. 2A-C). Histological analysis of horizontal (Fig. $2 A-C$ ) and coronal (Fig. 2D-F) brain sections at P1 demonstrated that major gray matter structures were present in double mutants. In contrast, both commissural fiber tracts originating from neocortical pyramidal neurons (CC and AC), but not the archipalliar HC, were completely absent in double mutants (Fig. $2 C, F)$. We did not observe any evidence for $\mathrm{PB}$ formation or other aberrant fiber tracts in comprehensive histological screens along the rostrocaudal and dorsoventral axis of double mutant brains (data not shown). Formation of the CC was only affected in double mutants, but not in mutants expressing at least one copy of either Neurod2 (Fig. 2A,D) or Neurod6 (Fig. $2 B, E$ ). Formation of the AC was abolished in Neurod 2 mutants harboring only one intact Neurod6 allele (Neurod $2^{-/-}$;Neurod6 ${ }^{+/-}$; Fig. $2 E)$ but was unaffected in Neurod6 mutants with only one wildtype Neurod 2 allele (Neurod2 $2^{+/-}$;Neurod6 ${ }^{-1-}$; Fig. 2D).

We noticed anomalies in numbers and positioning of cortical neurons that were most prominent in the somatosensory cortex (Fig. 2C). Although the detailed analysis of migration and cellular differentiation will be subject of another study, we next asked whether abolished axon tract formation in Neurod2/6 doublemutant mice could simply result from failed production of distinct projection neuron subtypes. Immunostaining for Nestin, Tbr2, and Ctip2 at E13 demonstrated normal production and radial migration of deeper layer neurons in Neurod2/6 doublemutant mice (Fig. 3A). Brn2 staining at E16 revealed normal invasion of upper layer neurons into the Neurod2/6 doublemutant neocortex (Fig. 3B). However, labeling of upper (Satb2) and deeper (Ctip2) layer neurons at P1 suggested mild alterations of radial migration and numbers of cortical neurons in $\mathrm{Neu}$ rod2/6 double mutants (Fig. $3 C$ ). When we quantified the cortical distribution of projection neurons at $\mathrm{P} 1$, we observed a reduction in the total number of Satb2-positive [control, $673 \pm 60$; double knock-out (DKO), $520 \pm 40$ cells per radial unit; $p=0.074]$ and Sox5-positive (control, $318 \pm 30$; DKO, $216 \pm 18$; $p=0.026$ ) neurons in upper and deeper cortical layers, respectively, whereas the total number of Ctip2-positive (control, $258 \pm 21$; DKO, $237 \pm 16 ; p=0.57$ ) neurons was unchanged (Fig. $3 D$ ). To further address the fate of postmigratory upper layer neurons, we performed additional immunostainings for Lmo4 (Fig. 3E) and Brn2 (Fig. 3F) and in situ hybridization for Cux2 (Fig. 3G) at P1. These studies confirmed the presence of differentiated upper layer neurons in Neurod2/6 double mutants but revealed changes in their exact laminar position. We conclude that callosal projection neurons are correctly specified in Neurod2/6 double mutants and that the majority of these cells survive, at least until birth.

\section{Callosal axogenesis is stalled before midline interactions in Neurod2/6 double mutants}

Callosal agenesis often results from impaired axon-midline glia interactions (Lindwall et al., 2007). However, Neurod2 and Neu- 

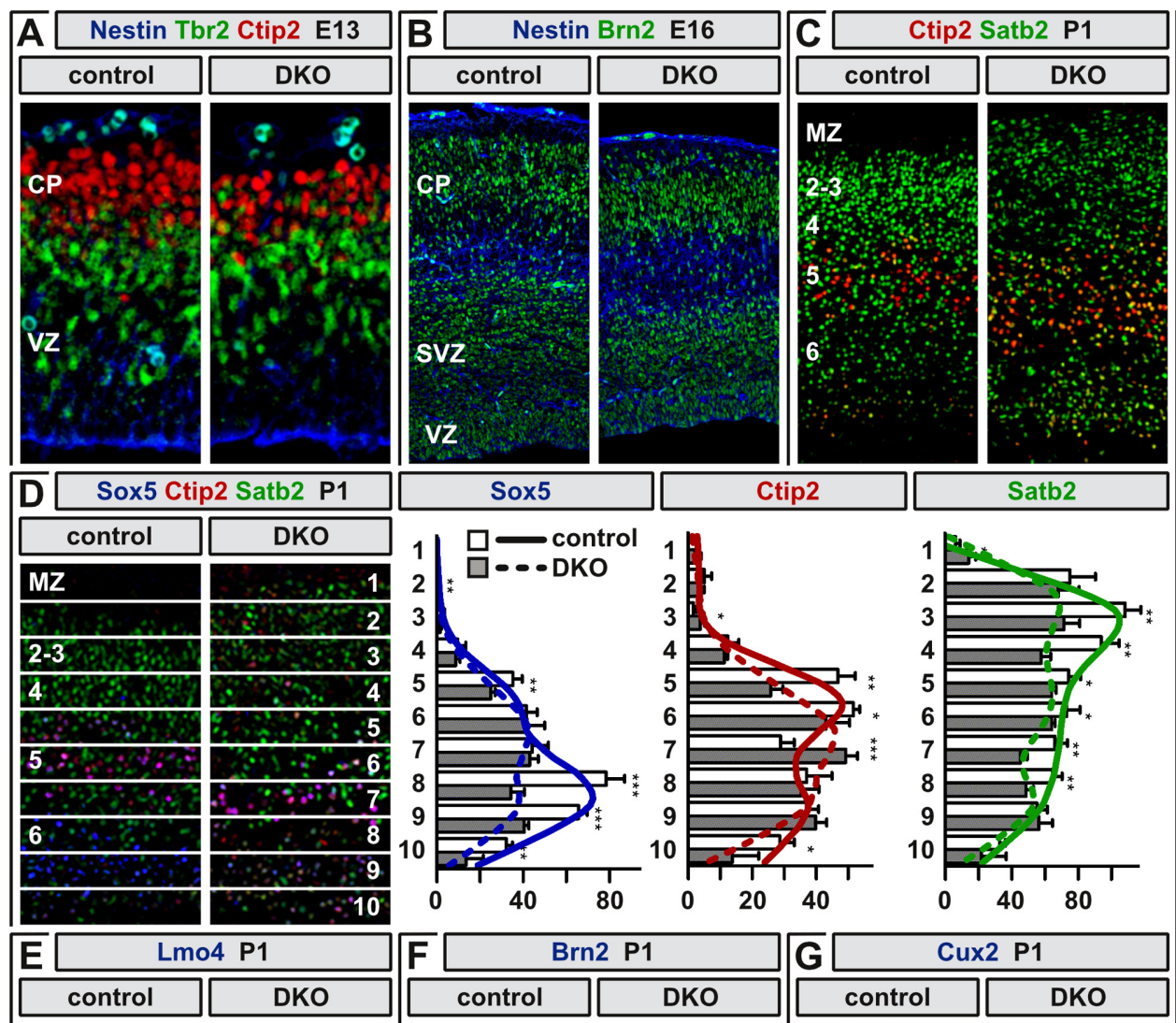

\begin{tabular}{|l|}
\hline Brn2 P1 \\
\hline control \\
\hline DKO
\end{tabular}
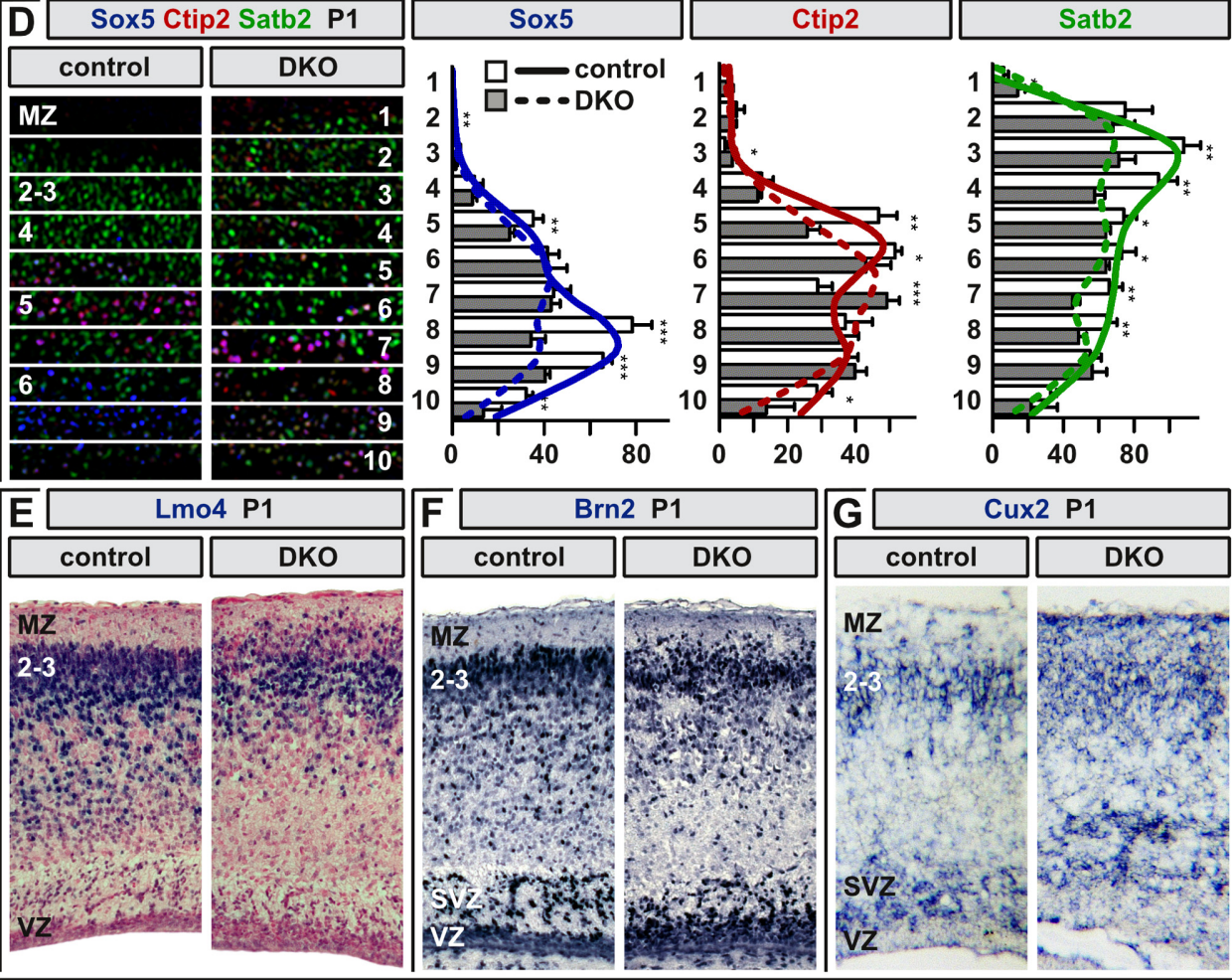

Figure 3. Projection neurons adopt cortical layer-specific fates in Neurod2/6 double mutants. A, Fluorescent immunostaining for Nestin (blue), Tbr2 (green), and (Ctip2 (red) at E13 demonstrates normal CP formation and radial migration of early-born deeper layer projection neurons. $B$, Immunostaining for Nestin (blue) and Brn2 (green) at E16 reveals normal radial migration of upper layer neurons. C, Disturbed segregation of upper and deeper layers at P1 as demonstrated by immunostaining for Satb2 (green) and Ctip2 (red). D, Cortical distribution of Sox5-, Ctip2-, and Satb2-positive neurons in controls $(n=5$ mice) and Neurod2/6 double mutants $(n=4)$. The histograms show absolute cell numbers in 10 equally sized bins as denoted in C. $p$ values (two-sided t test) are displayed as ${ }^{*} p<0.05,{ }^{* *} p<0.01$, and ${ }^{* * *} p<0.001$. For regression curves, cells were counted in 50 equally sized bins. $\boldsymbol{E}-\boldsymbol{G}$, Expression analysis of upper layer-enriched markers by chromogenic immunostaining for $\operatorname{Lm0} 4(\boldsymbol{E})$, Brn2 $(\boldsymbol{F})$, and in situ hybridization for Cux2 mRNA (G). Coronal $(\boldsymbol{A}-\boldsymbol{C}, \boldsymbol{F}, \boldsymbol{G})$, horizontal (D), and sagittal $(\boldsymbol{E})$ paraffin sections $(5 \mu \mathrm{m})$ from control and Neurod2/6 double-mutant brains. 2-6, Cortical layers; MZ, marginal zone.

rod6 are not expressed in midline glia (Lin et al., 2004; Goebbels et al., 2006; Fig. 1), and immunostaining for Gfap at P1 revealed no obvious changes in the structure of midline glia components (Fig. $4 A)$, supporting the hypothesis that the defect is intrinsic to double-mutant projection neurons.

To selectively monitor axonal trajectories of cortical projection neurons, we expressed GFP under control of a chicken $\beta$-actin/CMV fusion promoter in the cortex of E15 embryos (a time point when upper layer callosal neurons are generated) by in utero electroporation (Fig. 4B-D). Confocal microscopy of coronal brain sections from control mice at P1 revealed GFP-positive callosal axons that followed a stereotypic trajectory and eventually crossed the midline (Fig. 4B). Similar to controls, callosal axons in double mutants turned medially after leaving the $\mathrm{CP}$ and followed a tangential path. However, axons were stalled in the
SVZ of the cingulate cortex and failed to turn ventrally toward the midline (Fig. 4C). At their leading edge, axon bundles defasciculated and individual axons followed irregular, e.g., dorsal, trajectories into the ipsilateral CP (Fig. $4 C$, arrowheads). Consistent with our histological analysis, we never observed signs of $\mathrm{PB}$ formation. Importantly, expression of GFP in the cingulate cortex visualized axons of pioneer neurons that crossed the midline even in double-mutant mice (Fig. 4D), further demonstrating that the relevant midline structures are intact.

In rare cases, Neurod2/6 double-mutant mice survived postnatal stages. Double mutants were severely growth retarded (reaching only $\sim 30 \%$ of normal body size and weight at 1 month of age) and displayed spastic motor dysfunction. Two hand-fed double mutants survived until P60. NeuN staining revealed reduced neuronal cell numbers, but a fraction of neurons survived 
in the double-mutant cortex (Fig. 5A). Moreover, immunohistochemistry for neurofilament medium subunit (Fig. 5B) and myelin protein $C N P$ (Fig. $5 C$ ) confirmed permanent and complete CC agenesis in the absence of Neurod2 and Neurod6. In addition to the atrophy of fiber tracts, Map2-positive dendrites, although present at a similar overall density, were heavily disorganized in double mutants (Fig. 5D). Because midline crossing of layer II/III-derived callosal axons proceeds through postnatal stages, these findings demonstrate that combined Neurod2 and Neurod6 deficiency affects all classes of callosal neurons and that commissure formation is permanently abolished, not developmentally delayed, in Neurod2/6 double mutants. We conclude that Neurod2 and Neurod6 cooperatively control an intrinsic molecular program that is essential for axonal fasciculation, extension of compact fiber tracts, and midline crossing of neocortical projection neurons.

\section{Reduced glutamatergic network activity} in the absence of Neurod 2/6

GFP labeling of cortical neurons by in utero electroporation identified major deficits in the extension of compact fiber tracts but suggested normal axon outgrowth from Neurod2/6 double-mutant neurons (Fig. 4). To monitor initial axon outgrowth from individual cells, we filled upper layer projection neurons (born at approximately E16) with Lucifer yellow in cortical slices prepared from E18 mice. As expected from our previous findings, we observed normal radially oriented axonal outgrowth from double-mutant neurons when compared with controls (Fig. 6A). Normal neurite growth from doublemutant neurons was also confirmed by F-actin staining of cortical cell cultures prepared at E16 after 7 DIV (Fig. 6B). These findings strongly suggest that Neurod $2 / 6$ regulate an intermediate stage of axon tract formation before midline interactions but after initial axon outgrowth.

Neurod2 regulates the maturation of glutamatergic thalamocortical and hippocampal synapses (InceDunn et al., 2006; Wilke et al., 2012). Consistent with these findings, immunostaining of Neurod2/6 double mutants at P60 revealed reduced neocortical expression of two critical components of glutamatergic synapses, Vglut1 (Fig. 6C) and NR1 (Fig. $6 D)$. To study the long-term effects of impaired axon tract formation on glutamatergic network activity, we prepared cortical cell cultures from double mutants and controls at P1 and maintained them for up to 28 DIV (Fig. 6E). Consistent with our findings in the two surviving Neurod2/6 double mutants (Fig. 5), the axonal compartment (defined by Gap43-positive axon bundles) was reduced in cultures derived from Neurod2/6 double mutants when compared with controls (Fig. 6E; control, $2085 \pm$

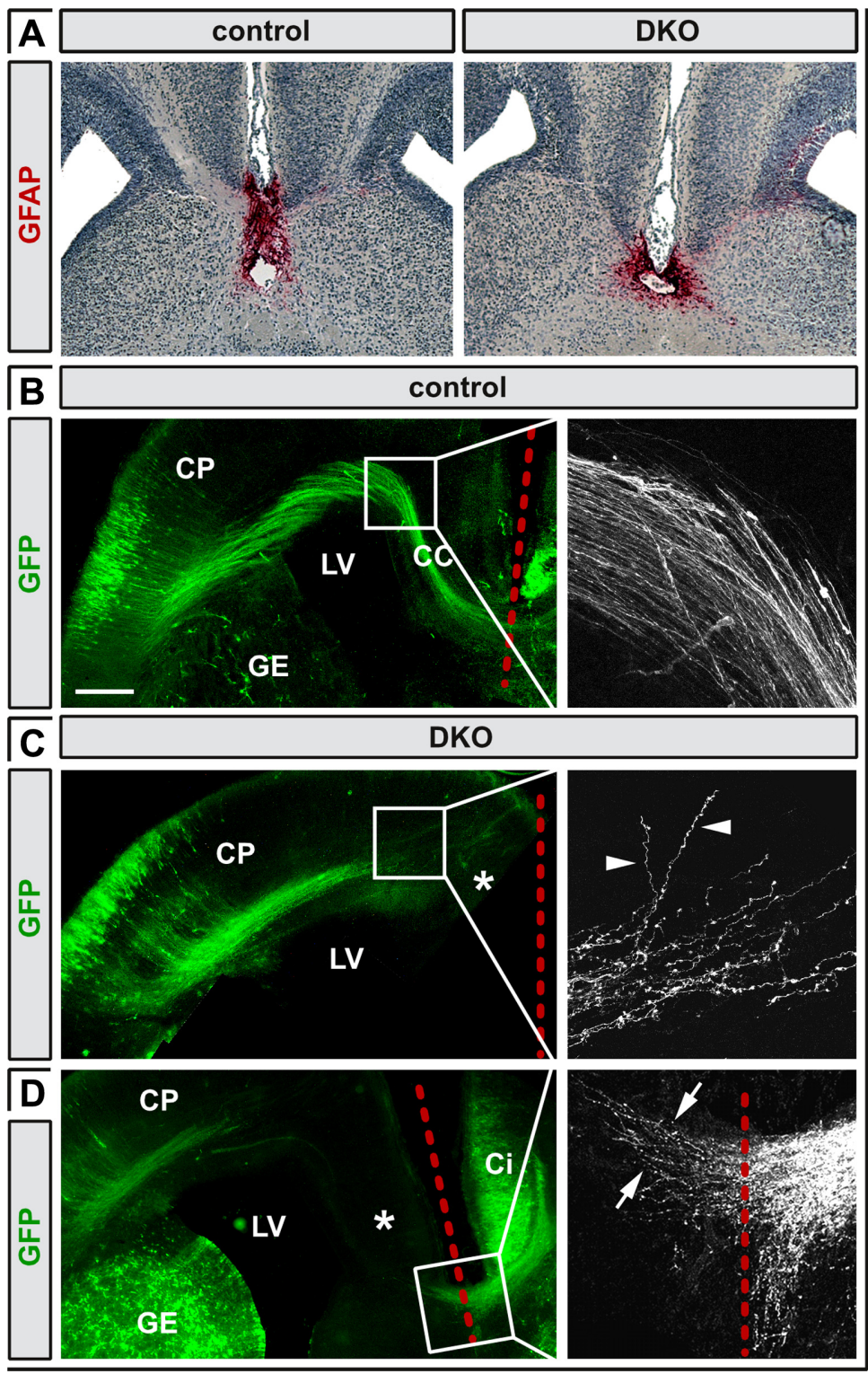

Figure 4. Callosal axons defasciculate and fail to grow toward the midline in the absence of Neurod2/6. $A$, GFAP immunostaining of midline glia in coronal sections of control and Neurod2/6 double-mutant brains at P1. $\boldsymbol{B}-\boldsymbol{D}$, Microscopy of coronal brain sections at $P 1$ after in utero electroporation of $\beta$-actin/CMV promoter-driven Venus-GFP at E15 identifies callosal axons in control brains that crossed the midline following a stereotypic trajectory $(\boldsymbol{B})$. In contrast, double-mutant axons never approached the midline (asterisks in $\boldsymbol{C}$ ) but were stalled after reaching the SVZ of the cingulate cortex ( $\boldsymbol{C}$ ). Higher magnification reveals that mutant derived from electroporated neurons in the contralateral cingulate cortex crossed the midline even in double mutants (arrows in D). Red dashed lines mark the midline. Scale bar, $250 \mu \mathrm{m}$. Ci, Cingulate cortex; GE, ganglionic eminence; LV, lateral ventricle.

$145 \mu \mathrm{m}$; DKO, $1243 \pm 261 \mu \mathrm{m}$ per field of view; $n=2$ mice). To measure the activity of glutamatergic synapses, we recorded spontaneous EPSCs (sEPSCs) by patch-clamp recording from cortical cell cultures at 21-28 DIV. Spontaneous burst activity was almost completely lost in double-mutant cultures compared with controls (Fig. $6 F$; control, $\sim 15$ burst $/ 3 \mathrm{~min}$; DKO, $<1$ bursts/3 $\mathrm{min}$ ), indicating strongly reduced network activity in double mutants. Moreover, the frequency of background sEPSCs was strongly reduced in double-mutant cultures (Fig. 6F; control, $17.8 \pm 2.1 \mathrm{~Hz}, n=20$ cells $/ 12$ wells; $\mathrm{DKO}, 4.9 \pm 1.3 \mathrm{~Hz}, n=14$ cells/12 wells; $p<0.001$ ), and sEPSC amplitude was clearly reduced when compared with controls (Fig. $6 F$; control, $59.5 \pm 5$ $\mathrm{pA}$; DKO, $40.3 \pm 2.5 \mathrm{pA} ; p<0.01)$. We conclude that the loss of 

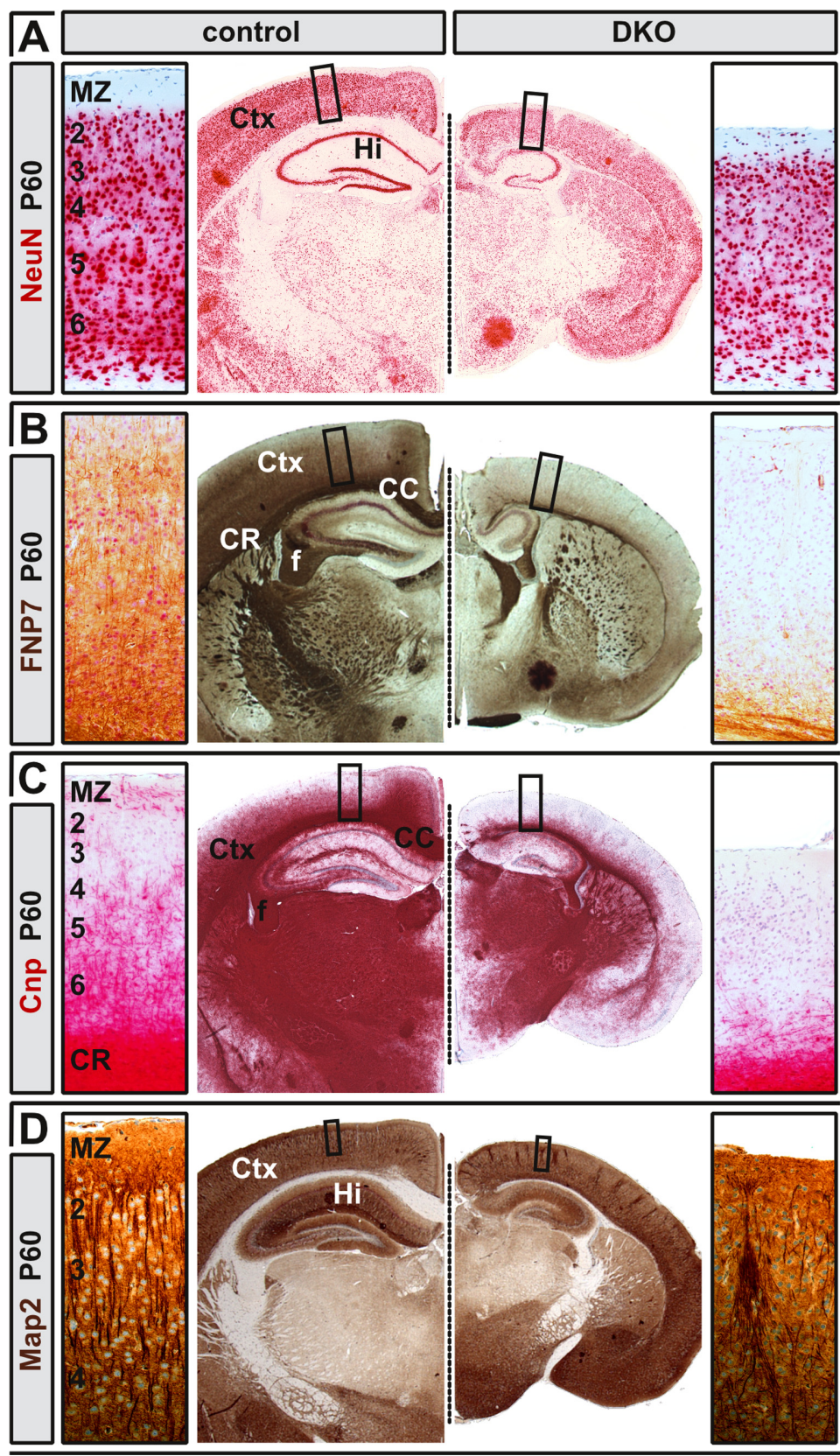

Figure 5. PermanentCC agenesis in adult Neurod2/6 double mutants. $\boldsymbol{A}$, The number of NeuN-positive neurons in the neocortex of double mutants at 2 months of age was mildly reduced when compared with a littermate control with genotype Neurod $2^{+/-}$. Neurod6 ${ }^{-1-} . \boldsymbol{B}, \boldsymbol{C}$, Midline crossing of FNP7 $(\boldsymbol{B})$ and CNP-positive $(\boldsymbol{C})$ fibers was permanently abolished in double mutants. $\boldsymbol{D}$, Map2-positive cortical dendrites were highly disorganized in the double-mutant neocortex, but their overall density was similar compared with control. CR, Coronal radiation; $f$, fimbria.

Neurod 2 and Neurod6 resulted in a severe reduction in the number of functional glutamatergic synapses and as a consequence in strongly diminished excitatory network activity in doublemutant cortical cell cultures.

\section{Misexpression of axonal signaling receptors Cntn2 and Robo1 in Neurod 2/6 double mutants \\ Ig domain-containing neural cell adhesion molecules (IgCAMs) are required for axonal fasciculation and commissure formation (Andrews et al., 2007; Katidou et al., 2008). To identify molecular deficits that may underlay reduced cortical connectivity in $\mathrm{Neu}$ - rod2/6 double mutants, we examined the expression of various IgCAMs. Most of the tested candidates were normally expressed}
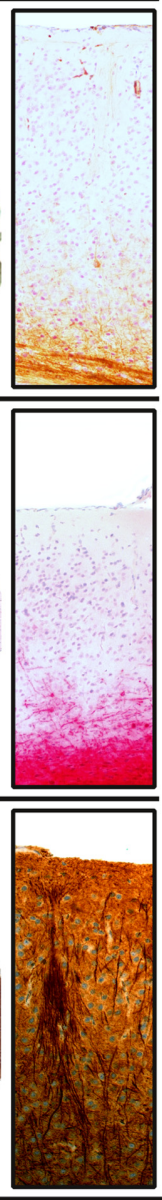

in Neurod2/6 double-mutant brain tissue (Fig. $7 E, H$; and not shown). In contrast, Cntn2 expression was virtually lost and Robo1 was upregulated in Neurod2/6 double mutants.

Fluorescent immunostaining of control brains at $\mathrm{P} 1$ demonstrated prominent Cntn2 protein expression on callosal and hippocampal axons, whereas L1cam staining additionally marked Neurod2/6negative thalamocortical afferents (Fig. $7 A)$. In stark contrast, Cntn2-positive axons were completely absent from the neocortex of Neurod2/6 double mutants, whereas the Cntn2-positive HC persisted (Fig. 7A). In situ hybridizations at P1 (Fig. $7 B$ ) and E16 (Fig. $7 F$ ) revealed an almost complete absence of Cntn2 transcripts from neocortical pyramidal neurons, whereas hippocampal expression was essentially unaffected. By quantitative real-time PCR at P1, Cntn2 expression in laser-captured sensory neocortex from double mutants was reduced by $\sim 80 \%$ compared with controls (Fig. 7E). In contrast, mRNA levels of the closely related IgCAM Cntn1 as well as expression of L1Cam and Gap43 were not significantly altered (Fig. $7 E, H$ ).

By immunostaining of horizontal brain sections at P1, we identified Robo1positive callosal axons that crossed the midline in controls but not in double mutants (Fig. 7C). Moreover, although protein levels were low in the neocortex of controls, Robol was increased in double mutants and delineated radially oriented axonal aggregates that were separated by Robol-free domains (Fig. 7C). Upregulated Robol expression in double mutants was confirmed by quantitative real-time PCR (Fig. 7E) and in situ hybridization at P1 (Fig. 7D) and E16 (Fig. 7G). Because Neurod2 and Neurod6 act as positive transcriptional regulators, these data suggest that Robol expression is under distinct transcriptional control.

In summary, we conclude that neocortical projection neurons require transcriptional specification by neuronal bHLH proteins to assemble and extend neocortical commissures. Our data suggest that abolished commissure formation results from axonal fasciculation deficits before midline interactions.

\section{Discussion}

Glutamatergic projection neurons are the main neuronal component of cortical gray matter and essential for higher cognitive functions. In this study, we show that neuronal bHLH proteins Neurod 2 and Neurod6 are critically required for the transcriptional specification of callosal long-range axogenesis and the establishment of neocortical circuitry. 


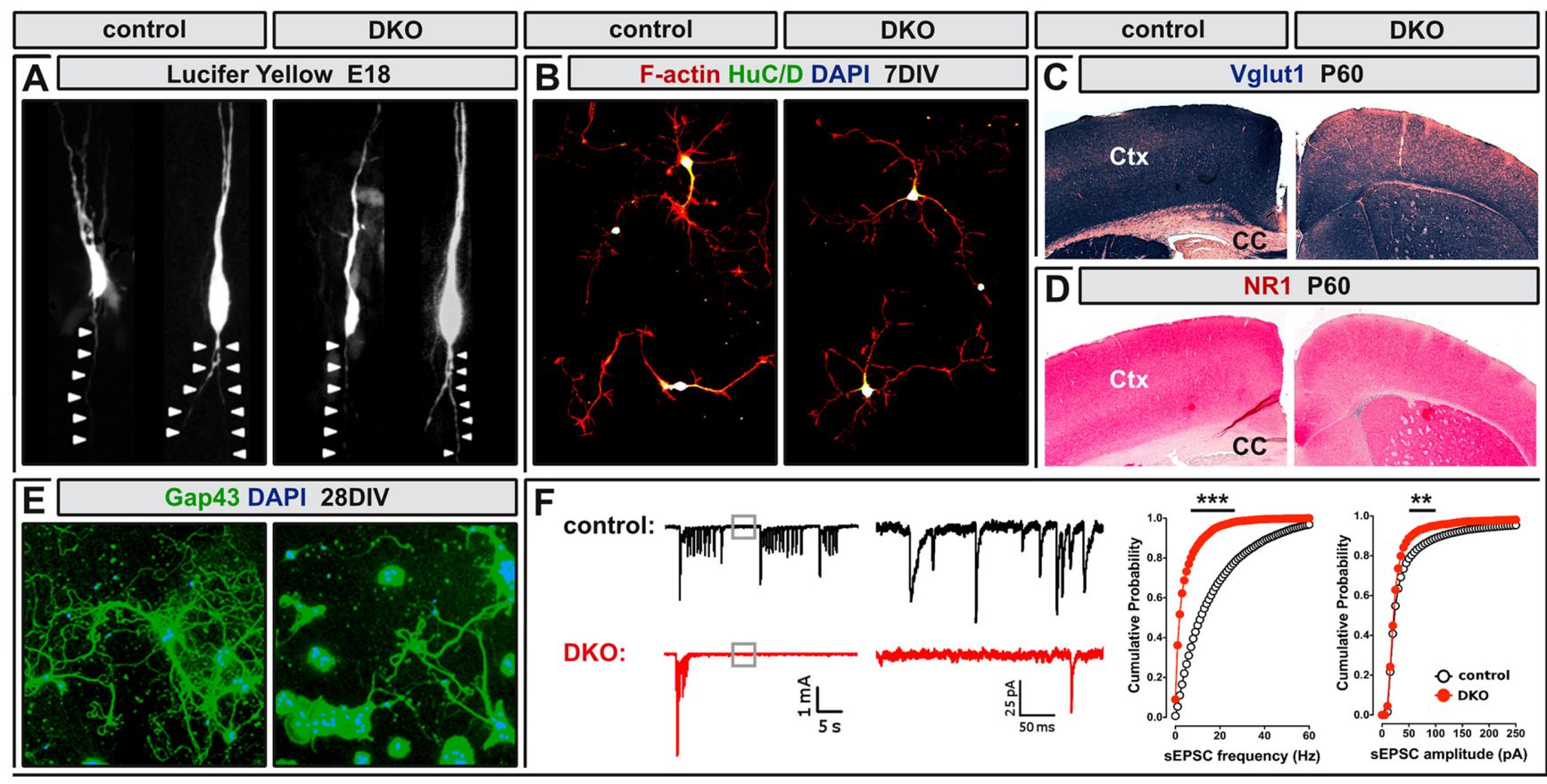

Figure 6. Axon growth and glutamatergic synaptogenesis in Neurod2/6 double mutants. A, Lucifer-yellow-filled projection neurons in upper layers of cortical slices prepared from control and Neurod2/6 double-mutant mice at E18. Axons are marked by arrowheads. B, Fluorescent staining for F-actin (red) combined with immunostaining for the neuronal marker HuC/D in cortical cell cultures prepared from P1 mice at 7 DIV. C, D, Reduced expression levels of presynaptic and postsynaptic components of glutamatergic synapses in the neocortex of adult double mutants. Immunostaining for Vglut $1(\boldsymbol{C})$ and NR1 (D) on coronal brain sections at 2 months of age. $\boldsymbol{E}$, Immunostaining for axon bundles (Gap43; green) and nuclei (DAPl; blue) in cortical cell cultures from P1 mice after $28 \mathrm{DIV} . \boldsymbol{F}$, Spontaneous excitatory synaptic activity in cortical cell cultures from control and double-mutant mice after 21-28 DIV by patch-clamp recording. Left, Spontaneous burst activity was recorded at $\sim 10$-fold higher frequency in control cultures ( 15 bursts $/ 3 \mathrm{~min} ; n=20$ cells) than in double-mutant cultures ( $<1$ burst $/ 3$ min; $n=14$ cells). Middle and right, The frequency of background sEPSC was strongly reduced in double-mutant cultures compared with controls. Str, Striatum. ${ }^{* *} p<0.01$ and ${ }^{* * *} p<0.001$.

\section{Formation of neocortical fiber tracts depends on highly} redundant neuronal bHLH protein functions

Transcription factors of the bHLH superfamily play instructive roles in mammalian organogenesis. Frequently, two to four closely related proteins serve overlapping functions, e.g., during myogenesis (Rudnicki et al., 1992) and retinal development (Inoue et al., 2001). In most cases, these factors are already expressed in proliferating progenitor cells, e.g., MyoD family members (Berkes and Tapscott, 2005) and the neurogenins (Fode et al., 2000; Ross et al., 2003). Here, we show that this functional principle also applies to postmitotic neuronal bHLH proteins Neurod2 and Neurod6. Although neocortical development is essentially unaffected in Neurod2 and Neurod6 single mutants (Schwab et al., 1998; Liu et al., 2000; Olson et al., 2001), neocortical fiber tract formation is severely impaired in Neurod2/6 double-mutant mice. Neurod 2 and Neurod 6 functions are highly overlapping because fiber tracts develop normally in the presence of one single wild-type allele of Neurod2 (in a Neurod6 null background) or Neurod6 (in a Neurod2 null background). Notably, the archipalliar HC develops normally and persists in the absence of both factors, demonstrating that Neurod2 and Neurod6 are not essential for the formation of this phylogenetically older fiber tract. We conclude that Neurod2/6-dependent and -independent transcriptional programs operate in phylogenetically and developmentally distinct subtypes of cortical projection neurons to orchestrate axon tract formation and the establishment of remote connectivity.

Cortical neurons survive at least to some extent in adult $\mathrm{Neu}$ rod2/6 double-mutant mice in the absence of significant contralateral target innervation. This suggests that, unlike cerebellar granule cells (Olson et al., 2001), projection neurons do not critically depend on contralateral target-derived trophic factors for their survival but may solely rely on local support from the ipsilateral hemisphere.

\section{Inactivation of Neurod $2 / 6$ causes an unique defect in early CC formation}

The majority of mouse mutants with callosal agenesis exhibit impairments in relatively late stages of axonal pathfinding, which are frequently associated with disturbed axon-midline interactions (Lindwall et al., 2007; Donahoo and Richards, 2009) and PB formation, e.g., null mutants of L1cam (Demyanenko et al., 1999), Gap43 (Shen et al., 2002), Dcc (Fazeli et al., 1997), Netrin-1 (Serafini et al., 1996), and Slit (Bagri et al., 2002) and Robol/2 double mutants (López-Bendito et al., 2007). Similarly, many mouse mutants for a diverse set of cortically expressed transcription factors display PB formation, including null mutants of Pax6 (Jones et al., 2002), Tbr1 (Hevner et al., 2001), and Coup-TF1 (Armentano et al., 2006). However, in Neurod2/6 double-mutant mice, midline crossing of pioneer axons and hippocampal fibers demonstrate that midline glia components are functional, and the absence of PB formation strongly suggests that loss of Neurod 2 and Neurod6 blocks CC formation at a stage proximal to pathfinding decisions at the midline.

We also found no evidence that mutant axons are misdirected toward other fiber tracts as observed for upper layer neurons in Satb2 mutants, in which callosal axons fasciculate and principally can cross the midline but are misdirected into $\mathrm{AC}$ and ipsilateral internal capsule (Alcamo et al., 2008; Britanova et al., 2008). Because expression of Satb2 is maintained in Neurod2/6 double mutants, we conclude that Neurod2/6 act upstream of Satb2. Our data also suggest that Neurod2/6 act downstream of Neurogenin 1 (Neurog1) and Neurog2, atonal-related bHLH proteins expressed in neuronal progenitors of the VZ (Ma et al., 1996; Som- 


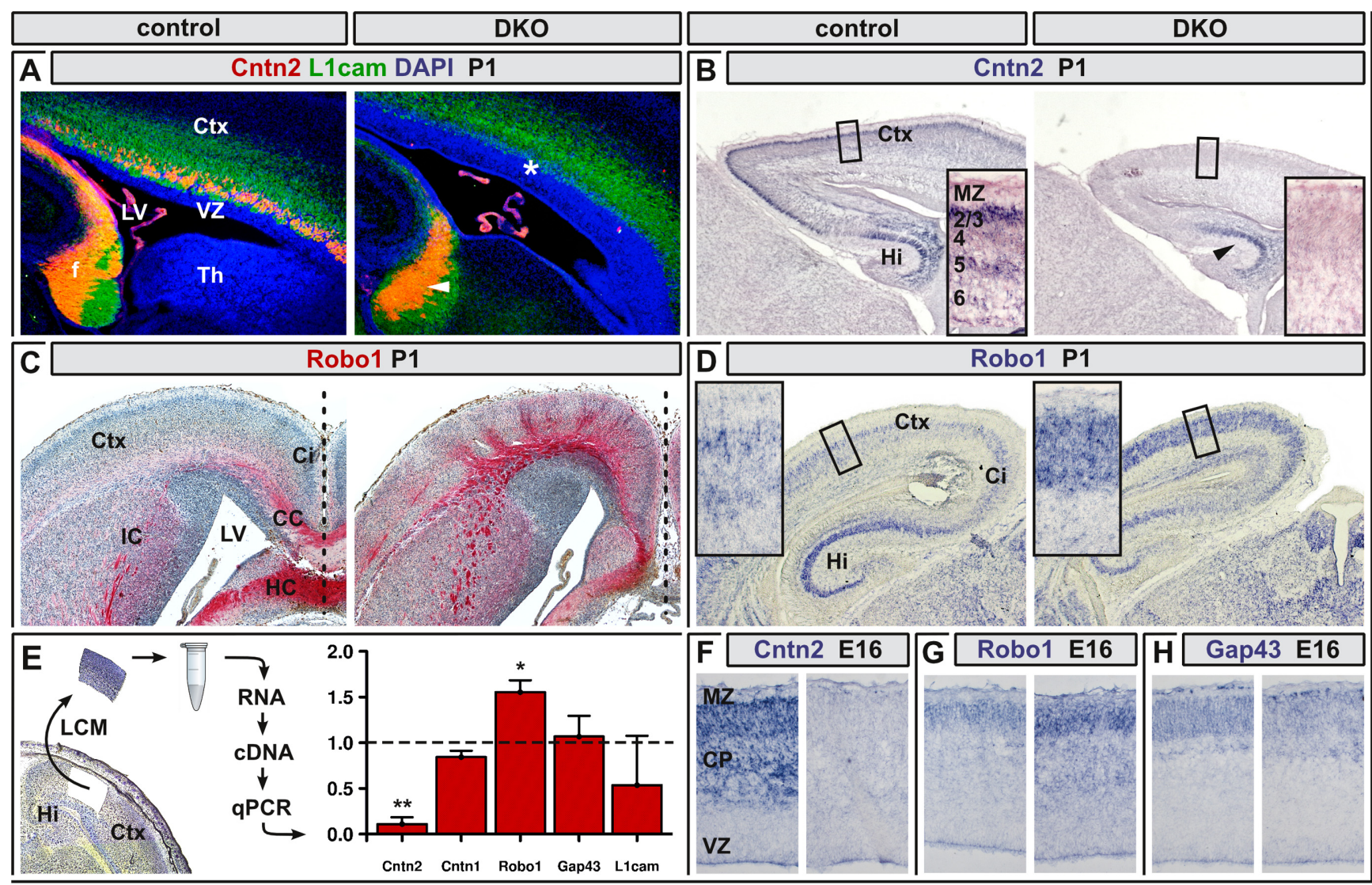

Figure 7. Differential expression of (ntn2 and Robo1 in Neurod2/6-deficient callosal projection neurons. A, Fluorescent immunostaining for Cntn2 (red) and L1cam (green) in parasagittal brain sections at P1. In control brains, Cntn2 expression marked callosal and hippocampal axons, whereas motor axons and thalamocortical afferents also expressed L1cam. In double mutants, Cntn2 expression was no longer detectable in callosal (asterisk) but preserved in hippocampal axons (arrowhead). B, Chromogenic in situ hybridization at P1 confirmed a strong reduction of Cntn2 transcripts in neocortex but persistent expression in the hippocampal CA1-CA3 region (arrowhead) of Neurod2/6 double mutants. C, Immunostaining for the Robo1 receptor on horizontal brain sections identified radially oriented Rob01-positive axonal aggregates in double mutants, which were not present in controls. D, Chromogenic in situ hybridization on coronal brain sections revealed increased expression of Robo1 mRNA in the neocortex of Neurod2/6 double mutants. $E$, Expression analysis by quantitative real time-PCR using LCM derived from serial brain sections at P1 (representative section is shown on left side). (ntn2 mRNA was reduced by $75.4 \pm 4.8 \%(p=0.0026)$, whereas Robol expression was increased by $44.4 \pm 1.5 \%(p=0.0126)$ in double-mutant cortex. Expression levels of Cntn1, L1 cam, and Gap43 mRNA were not significantly altered in double mutants when compared with controls. F-H, Chromogenic in situ hybridization for Cntn2, Robo 1, and Gap43 transcripts at E16. Error bars show SEM. ${ }^{*} p<0.05,{ }^{* *} p<0.01 ; n=3$ mice per genotype. Th, Thalamus.

mer et al., 1996), which act as transcriptional activators of Neurod2 and Neurod6 (Schuurmans et al., 2004). Neurog2 regulates initial medially oriented callosal axon guidance (Hand and Polleux, 2011), and our data support the concept that Neurod2/6 serve as regulators of cortical commissure formation downstream of Neurog2.

\section{Dysregulation of axonal signaling receptors Cntn2 and Robo1 in Neurod2/6 double mutants}

CC formation proceeds through several developmental stages, including radial axon outgrowth, fasciculation, tangential axon bundle extension, midline crossing, contralateral target area innervation, and synaptogenesis (Richards et al., 2004; Donahoo and Richards, 2009). Based on the relatively normal expression pattern of callosal neuron-specific marker genes Lmo4 and Satb2 (Arlotta et al., 2005; Alcamo et al., 2008; Britanova et al., 2008) in upper layers of the primary motor cortex, we conclude that CC agenesis in double mutants is not caused by a general failure to specify and correctly position callosal neurons. Furthermore, radial axon outgrowth and initial tangential elongation are essentially unaffected. Thus, neuronal bHLH proteins are not essentially required for neurite outgrowth per se. Rather, we suggest a role in axonal fasciculation and elongation of compact fiber tracts through the regulated expression of axonal signaling receptors.

This hypothesis is supported by the dramatically reduced expression of Cntn2 mRNA in the neocortex (but not hippocampus) of double-mutant mice. Because callosal neurons are present in double mutants, we speculate that loss of Cntn2 expression is attributable to impaired transcriptional activation by Neurod 2 and Neurod6. Nevertheless, whether Cntn2 is a bona fide target gene of neuronal bHLH proteins requires additional investigation.

Cntn 2 controls axonal growth and fasciculation in vitro and in vivo (Maness and Schachner, 2007; Katidou et al., 2008). We suggest that the loss of Cntn2 contributes to defasciculation and diminished axonal elongation as a consequence of impaired interactions of callosal axons with ingrowing afferents and extracellular matrix-derived extracellular cues (Malhotra et al., 1998; Pavlou et al., 2002; Mikami et al., 2009). However, it is important to emphasize that loss of Cntn2 function alone is insufficient to cause the phenotype observed in double mutants because Cntn2deficient mice develop a grossly normal CC (Fukamauchi et al., 2001). It is therefore plausible that several IgCAMs serve as mediators of Neurod $2 / 6$ function. 
Robol, another IgCAM protein, is upregulated in the cortex of Neurod2/6 mutants. CC formation is perturbed in Robol/2 double mutants (López-Bendito et al., 2007), but the exact mechanism is unknown. Robol serves as a receptor for Slit proteins, a family of secreted chemorepellents expressed at the midline (Dickson and Gilestro, 2006). Thus, enhanced Robo1-Slit signaling in double mutants possibly interferes with tangential axon bundle extension toward the midline.

Neurod2 mutants show deficits in emotional learning (Lin et al., 2005), and Neurod6 mutants that are heterozygous for Neurod2 (genotype Neurod2 ${ }^{+/-}$;Neurod6 $6^{--}$) display pathological social behavior as well as reduced mating and fostering activity (I.B. and M.H.S., unpublished observation). TCF4 (ME2), the main dimerization partner for neuronal bHLH proteins in the cortex, is encoded by one of the most significant schizophrenia susceptibility genes (Stefansson et al., 2009). Transgenic mice that overexpress TCF4 in CNS neurons display cognitive and sensorimotor gating impairments (Brzózka et al., 2010). Disrupted Cntn2 function in mouse mutants causes learning and memory deficits (Savvaki et al., 2008), and Cntn2 forms complexes with Contactin-associated protein 2 (Cntnap2, Caspr2), a genetic risk factor for schizophrenia, autism (Burbach and van der Zwaag, 2009), and specific language disorder (Vernes et al., 2008). Thus, in addition to establishing cortical circuitry during development, neuronal bHLH proteins may also regulate learning and memory processes in the mature brain, and altered expression of their target genes might provide a link to neuropsychiatric disorders, such as schizophrenia.

\section{References}

Agarwal A, Dibaj P, Kassmann CM, Goebbels S, Nave KA, Schwab MH (2012) In vivo imaging and noninvasive ablation of pyramidal neurons in adult NEX-CreERT2 mice. Cereb Cortex 22:1473-1486. CrossRef Medline

Alcamo EA, Chirivella L, Dautzenberg M, Dobreva G, Fariñas I, Grosschedl R, McConnell SK (2008) Satb2 regulates callosal projection neuron identity in the developing cerebral cortex. Neuron 57:364-377. CrossRef Medline

Andrews WD, Barber M, Parnavelas JG (2007) Slit-Robo interactions during cortical development. J Anat 211:188-198. CrossRef Medline

Angevine JB Jr, Sidman RL (1961) Autoradiographic study of cell migration during histogenesis of cerebral cortex in the mouse. Nature 192:766-768. CrossRef Medline

Arimura N, Kaibuchi K (2007) Neuronal polarity: from extracellular signals to intracellular mechanisms. Nat Rev Neurosci 8:194-205. CrossRef Medline

Arlotta P, Molyneaux BJ, Chen J, Inoue J, Kominami R, Macklis JD (2005) Neuronal subtype-specific genes that control corticospinal motor neuron development in vivo. Neuron 45:207-221. CrossRef Medline

Armentano M, Filosa A, Andolfi G, Studer M (2006) COUP-TFI is required for the formation of commissural projections in the forebrain by regulating axonal growth. Development 133:4151-4162. CrossRef Medline

Bagri A, Marín O, Plump AS, Mak J, Pleasure SJ, Rubenstein JL, TessierLavigne M (2002) Slit proteins prevent midline crossing and determine the dorsoventral position of major axonal pathways in the mammalian forebrain. Neuron 33:233-248. CrossRef Medline

Barnes AP, Polleux F (2009) Establishment of axon-dendrite polarity in developing neurons. Annu Rev Neurosci 32:347-381. CrossRef Medline

Bartholomä A, Nave KA (1994) NEX-1: a novel brain-specific helix-loophelix protein with autoregulation and sustained expression in mature cortical neurons. Mech Dev 48:217-228. CrossRef Medline

Berkes CA, Tapscott SJ (2005) MyoD and the transcriptional control of myogenesis. Semin Cell Dev Biol 16:585-595. CrossRef Medline

Britanova O, de Juan Romero C, Cheung A, Kwan KY, Schwark M, Gyorgy A, Vogel T, Akopov S, Mitkovski M, Agoston D, Sestan N, Molnár Z, Tarabykin V (2008) Satb2 is a postmitotic determinant for upper-layer neuron specification in the neocortex. Neuron 57:378-392. CrossRef Medline

Brzózka MM, Radyushkin K, Wichert SP, Ehrenreich H, Rossner MJ (2010)
Cognitive and sensorimotor gating impairments in transgenic mice overexpressing the schizophrenia susceptibility gene Tcf4 in the brain. Biol Psychiatry 68:33-40. CrossRef Medline

Burbach JP, van der Zwaag B (2009) Contact in the genetics of autism and schizophrenia. Trends Neurosci 32:69-72. CrossRef Medline

Cherry TJ, Wang S, Bormuth I, Schwab M, Olson J, Cepko CL (2011) NeuroD factors regulate cell fate and neurite stratification in the developing retina. J Neurosci 31:7365-7379. CrossRef Medline

Demyanenko GP, Tsai AY, Maness PF (1999) Abnormalities in neuronal process extension, hippocampal development, and the ventricular system of L1 knock-out mice. J Neurosci 19:4907-4920. Medline

Dickson BJ, Gilestro GF (2006) Regulation of commissural axon pathfinding by Slit and its Robo receptors. Annu Rev Cell Dev Biol 22:651-675. CrossRef Medline

Donahoo AL, Richards LJ (2009) Understanding the mechanisms of callosal development through the use of transgenic mouse models. Semin Pediatr Neurol 16:127-142. CrossRef Medline

Fazeli A, Dickinson SL, Hermiston ML, Tighe RV, Steen RG, Small CG, Stoeckli ET, Keino-Masu K, Masu M, Rayburn H, Simons J, Bronson RT, Gordon JI, Tessier-Lavigne M, Weinberg RA (1997) Phenotype of mice lacking functional Deleted in colorectal cancer (Dcc) gene. Nature 386: 796-804. CrossRef Medline

Fode C, Ma Q, Casarosa S, Ang SL, Anderson DJ, Guillemot F (2000) A role for neural determination genes in specifying the dorsoventral identity of telencephalic neurons. Genes Dev 14:67-80. CrossRef Medline

Fukamauchi F, Aihara O, Wang YJ, Akasaka K, Takeda Y, Horie M, Kawano H, Sudo K, Asano M, Watanabe K, Iwakura Y (2001) TAG-1-deficient mice have marked elevation of adenosine Al receptors in the hippocampus. Biochem Biophys Res Commun 281:220-226. CrossRef Medline

Goebbels S, Bormuth I, Bode U, Hermanson O, Schwab MH, Nave KA (2006) Genetic targeting of principal neurons in neocortex and hippocampus of NEX-Cre mice. Genesis 44:611-621. CrossRef Medline

Hand R, Polleux F (2011) Neurogenin2 regulates the initial axon guidance of cortical pyramidal neurons projecting medially to the corpus callosum. Neural Dev 6:30. CrossRef Medline

Hevner RF, Shi L, Justice N, Hsueh Y, Sheng M, Smiga S, Bulfone A, Goffinet AM, Campagnoni AT, Rubenstein JL (2001) Tbrl regulates differentiation of the preplate and layer 6. Neuron 29:353-366. CrossRef Medline

Huang HP, Chu K, Nemoz-Gaillard E, Elberg D, Tsai MJ (2002) Neogenesis of $\beta$-cells in adult BETA2/NeuroD-deficient mice. Mol Endocrinol 16: 541-551. CrossRef Medline

Ince-Dunn G, Hall BJ, Hu SC, Ripley B, Huganir RL, Olson JM, Tapscott SJ, Ghosh A (2006) Regulation of thalamocortical patterning and synaptic maturation by NeuroD2. Neuron 49:683-695. CrossRef Medline

Innocenti GM, Price DJ (2005) Exuberance in the development of cortical networks. Nat Rev Neurosci 6:955-965. CrossRef Medline

Inoue C, Bae SK, Takatsuka K, Inoue T, Bessho Y, Kageyama R (2001) Math6, a bHLH gene expressed in the developing nervous system, regulates neuronal versus glial differentiation. Genes Cells 6:977-986. CrossRef Medline

Jones L, López-Bendito G, Gruss P, Stoykova A, Molnár Z (2002) Pax6 is required for the normal development of the forebrain axonal connections. Development 129:5041-5052. Medline

Katidou M, Vidaki M, Strigini M, Karagogeos D (2008) The immunoglobulin superfamily of neuronal cell adhesion molecules: lessons from animal models and correlation with human disease. Biotechnol J 3:1564-1580. CrossRef Medline

Kay JN, Voinescu PE, Chu MW, Sanes JR (2011) Neurod6 expression defines new retinal amacrine cell subtypes and regulates their fate. Nat Neurosci 14:965-972. CrossRef Medline

Kume H, Maruyama K, Tomita T, Iwatsubo T, Saido TC, Obata K (1996) Molecular cloning of a novel basic helix-loop-helix protein from the rat brain. Biochem Biophys Res Commun 219:526-530. CrossRef Medline

Lin CH, Stoeck J, Ravanpay AC, Guillemot F, Tapscott SJ, Olson JM (2004) Regulation of neuroD2 expression in mouse brain. Dev Biol 265:234-245. CrossRef Medline

Lin CH, Hansen S, Wang Z, Storm DR, Tapscott SJ, Olson JM (2005) The dosage of the neuroD2 transcription factor regulates amygdala development and emotional learning. Proc Natl Acad Sci U S A 102:1487714882. CrossRef Medline

Lindwall C, Fothergill T, Richards LJ (2007) Commissure formation in the mammalian forebrain. Curr Opin Neurobiol 17:3-14. CrossRef Medline 
Liu M, Pleasure SJ, Collins AE, Noebels JL, Naya FJ, Tsai MJ, Lowenstein DH (2000) Loss of BETA2/NeuroD leads to malformation of the dentate gyrus and epilepsy. Proc Natl Acad Sci U S A 97:865-870. CrossRef Medline

López-Bendito G, Flames N, Ma L, Fouquet C, Di Meglio T, Chedotal A, Tessier-Lavigne M, Marín O (2007) Robo1 and Robo2 cooperate to control the guidance of major axonal tracts in the mammalian forebrain. J Neurosci 27:3395-3407. CrossRef Medline

Ma Q, Kintner C, Anderson DJ (1996) Identification of neurogenin, a vertebrate neuronal determination gene. Cell 87:43-52. CrossRef Medline

Malhotra JD, Tsiotra P, Karagogeos D, Hortsch M (1998) Cis-activation of L1-mediated ankyrin recruitment by TAG-1 homophilic cell adhesion. J Biol Chem 273:33354-33359. CrossRef Medline

Maness PF, Schachner M (2007) Neural recognition molecules of the immunoglobulin superfamily: signaling transducers of axon guidance and neuronal migration. Nat Neurosci 10:19-26. CrossRef Medline

Mihrshahi R (2006) The corpus callosum as an evolutionary innovation. J Exp Zool B Mol Dev Evol 306:8-17. CrossRef Medline

Mikami T, Yasunaga D, Kitagawa H (2009) Contactin-1 is a functional receptor for neuroregulatory chondroitin sulfate-E. J Biol Chem 284: 4494-4499. CrossRef Medline

Molyneaux BJ, Arlotta P, Menezes JR, Macklis JD (2007) Neuronal subtype specification in the cerebral cortex. Nat Rev Neurosci 8:427-437. CrossRef Medline

O’Donnell M, Chance RK, Bashaw GJ (2009) Axon growth and guidance: receptor regulation and signal transduction. Annu Rev Neurosci 32:383412. CrossRef Medline

Olson JM, Asakura A, Snider L, Hawkes R, Strand A, Stoeck J, Hallahan A, Pritchard J, Tapscott SJ (2001) NeuroD2 is necessary for development and survival of central nervous system neurons. Dev Biol 234:174-187. CrossRef Medline

Parrish JZ, Emoto K, Kim MD, Jan YN (2007) Mechanisms that regulate establishment, maintenance, and remodeling of dendritic fields. Annu Rev Neurosci 30:399-423. CrossRef Medline

Paul LK, Brown WS, Adolphs R, Tyszka JM, Richards LJ, Mukherjee P, Sherr EH (2007) Agenesis of the corpus callosum: genetic, developmental and functional aspects of connectivity. Nat Rev Neurosci 8:287-299. CrossRef Medline

Pavlou O, Theodorakis K, Falk J, Kutsche M, Schachner M, Faivre-Sarrailh C, Karagogeos D (2002) Analysis of interactions of the adhesion molecule TAG-1 and its domains with other immunoglobulin superfamily members. Mol Cell Neurosci 20:367-381. CrossRef Medline

Richards LJ, Plachez C, Ren T (2004) Mechanisms regulating the development of the corpus callosum and its agenesis in mouse and human. Clin Genet 66:276-289. CrossRef Medline

Ross SE, Greenberg ME, Stiles CD (2003) Basic helix-loop-helix factors in cortical development. Neuron 39:13-25. CrossRef Medline

Rudnicki MA, Braun T, Hinuma S, Jaenisch R (1992) Inactivation of MyoD in mice leads to up-regulation of the myogenic HLH gene Myf- 5 and results in apparently normal muscle development. Cell 71:383-390. CrossRef Medline

Saito T (2006) In vivo electroporation in the embryonic mouse central nervous system. Nat Protoc 1:1552-1558. CrossRef Medline

Sansom SN, Livesey FJ (2009) Gradients in the brain: the control of the development of form and function in the cerebral cortex. Cold Spring Harb Perspect Biol 1:a002519. CrossRef Medline

Savvaki M, Panagiotaropoulos T, Stamatakis A, Sargiannidou I, Karatzioula P, Watanabe K, Stylianopoulou F, Karagogeos D, Kleopa KA (2008) Im- pairment of learning and memory in TAG-1 deficient mice associated with shorter CNS internodes and disrupted juxtaparanodes. Mol Cell Neurosci 39:478-490. CrossRef Medline

Schuurmans C, Armant O, Nieto M, Stenman JM, Britz O, Klenin N, Brown C, Langevin LM, Seibt J, Tang H, Cunningham JM, Dyck R, Walsh C, Campbell K, Polleux F, Guillemot F (2004) Sequential phases of cortical specification involve Neurogenin-dependent and -independent pathways. EMBO J 23:2892-2902. CrossRef Medline

Schwab MH, Druffel-Augustin S, Gass P, Jung M, Klugmann M, Bartholomae A, Rossner MJ, Nave KA (1998) Neuronal basic helix-loop-helix proteins (NEX, neuroD, NDRF): spatiotemporal expression and targeted disruption of the NEX gene in transgenic mice. J Neurosci 18:1408-1418. Medline

Schwab MH, Bartholomae A, Heimrich B, Feldmeyer D, Druffel-Augustin S, Goebbels S, Naya FJ, Zhao S, Frotscher M, Tsai MJ, Nave KA (2000) Neuronal basic helix-loop-helix proteins (NEX and BETA2/Neuro D) regulate terminal granule cell differentiation in the hippocampus. J Neurosci 20:3714-3724. Medline

Serafini T, Colamarino SA, Leonardo ED, Wang H, Beddington R, Skarnes WC, Tessier-Lavigne M (1996) Netrin-1 is required for commissural axon guidance in the developing vertebrate nervous system. Cell 87:10011014. CrossRef Medline

Shen Y, Mani S, Donovan SL, Schwob JE, Meiri KF (2002) Growthassociated protein- 43 is required for commissural axon guidance in the developing vertebrate nervous system. J Neurosci 22:239-247. Medline

Sommer L, Ma Q, Anderson DJ (1996) Neurogenins, a novel family of atonal-related bHLH transcription factors, are putative mammalian neuronal determination genes that reveal progenitor cell heterogeneity in the developing CNS and PNS. Mol Cell Neurosci 8:221-241. CrossRef Medline

Stefansson H, Ophoff RA, Steinberg S, Andreassen OA, Cichon S, Rujescu D, Werge T, Pietiläinen OP, Mors O, Mortensen PB, Sigurdsson E, Gustafsson $\mathrm{O}$, Nyegaard $\mathrm{M}$, Tuulio-Henriksson A, Ingason A, Hansen T, Suvisaari J, Lonnqvist J, Paunio T, Børglum AD, et al. (2009) Common variants conferring risk of schizophrenia. Nature 460:744-747. CrossRef Medline

Vernes SC, Newbury DF, Abrahams BS, Winchester L, Nicod J, Groszer M, Alarcón M, Oliver PL, Davies KE, Geschwind DH, Monaco AP, Fisher SE (2008) A functional genetic link between distinct developmental language disorders. N Engl J Med 359:2337-2345. CrossRef Medline

Wilke SA, Hall BJ, Antonios JK, Denardo LA, Otto S, Yuan B, Chen F, Robbins EM, Tiglio K, Williams ME, Qiu Z, Biederer T, Ghosh A (2012) NeuroD2 regulates the development of hippocampal mossy fiber synapses. Neural Dev 7:9. CrossRef Medline

Wu SX, Goebbels S, Nakamura K, Nakamura K, Kometani K, Minato N, Kaneko T, Nave KA, Tamamaki N (2005) Pyramidal neurons of upper cortical layers generated by NEX-positive progenitor cells in the subventricular zone. Proc Natl Acad Sci U S A 102:17172-17177. CrossRef Medline

Yang Y, Kim AH, Yamada T, Wu B, Bilimoria PM, Ikeuchi Y, de la Iglesia N, Shen J, Bonni A (2009) A Cdc20-APC ubiquitin signaling pathway regulates presynaptic differentiation. Science 326:575-578. CrossRef Medline

Yasunami M, Suzuki K, Maruyama H, Kawakami H, Nagai Y, Hagiwara M, Ohkubo H (1996) Molecular cloning and characterization of a cDNA encoding a novel basic helix-loop-helix protein structurally related to Neuro-D/BHF1. Biochem Biophys Res Commun 220:754-758. CrossRef Medline 